\title{
EVALUASI SISTEM INFORMASI AKUNTANSI PENGUPAHAN PRODUKSI DALAM UPAYA EFEKTIVITAS PENGENDALIAN INTER- NAL PT.TM
}

\author{
Vera Margareta Tunjung Sari \\ Isharijadi \\ Elana Era Yusdita* \\ Universitas PGRI Madiun, Jalan Setia Budi 85, Madiun, Indonesia \\ elaradita@unipma.ac.id
}

\author{
A R T I C L E I N F O \\ Article history: \\ Received 30 July 2019 \\ Revised 19 December 2019 \\ Accepted 7January 2020
}

Key words:

Wages System, Production Sys-

tem,Internal Control Effectiveness

DOI:

10.33508/jako.v12i1.2091

\begin{abstract}
A B S T R A C T
This study is to evaluate the production wage accounting information system and the effectiveness of internal controls at PT. TM. The approach of this research is descriptive qualitative. This research was conducted at PT. TM in the period of 2019. The results show that the production wage accounting information system at PT. TM is in accordance with the procedures in the company but there is no flowchart. Internal control system for production wages at PT. TM has not been running effectively because there are still weaknesses such as still found multiple function in some parts and a lack of supervision of hired workers.
\end{abstract}

\begin{abstract}
A B S T R A K
Penelitian ini untuk mengevaluasi sistem informasi akuntansi pengupahan produksi dan efektivitas pengendalian internal di PT. TM. Pendekatan penelitian ini adalah kualitatif deskriptif. Penelitian ini dilakukan di PT. TM pada periode tahun 2019. Hasil menunjukkan bahwa sistem informasi akuntansi pengupahan produksi yang ada di PT. TM sudah sesuai dengan prosedur yang ada di perusahaan tetapi untuk alur flowchart belum ada. Sistem pengendalian internal atas pengupahan produksi di PT. TM belum berjalan dengan efektif karena masih ada kelemahan seperti masih ditemukan perangkapan tugas pada beberapa bagian dan kurangnya pengawasan pengupahan pekerja kasar.
\end{abstract}

\section{PENDAHULUAN}

Suatu sistem informasi mampu membantu aktivitas operasional perusahaan. Salah satu sistem informasi yang ada di perusahaan adalah sistem informasi akuntansi dimana proses pencatatan tersebut berbasis komputerisasi maupun manual.Pada sistem pengupahan yang ada di PT. TM pembayaran upah dilakukan berdasarkan sistem borongan yang berdasarkan jumlah produksi. Dalam melakukan pekerjaan borongan, pekerja kasar hanya akan bekerja apabila ada permintaan dan pembayaran pengupahan ini dilakukan setiap hari Jumat. Pada dasarnya suatu sistem informasi akuntansi jika tidak ada pengendalian internal maka akan terjadi penyelewengan oleh oknum yang tidak bertanggungjawab, pada PT. TM ini untuk pengendalian internal atau pengawasan pada saat pembagian upah kepada pekerja kasar belum berjalan dengan semestinya karena dalam proses pembayaran upah produksi ini yang menerima kwitansi hanya diwakilkan satu orang saja, selain itu masih terdapat perangkapan tugas pada karyawannya. Perangkapan tugas tersebut dikarenakan terjadinya kekurangan sumber daya manusia (SDM).

Sistem informasi akuntansi adalah suatu sistem yang memproses data transaksi untuk menghasilkan informasi yang bermanfaat guna mengambil keputusan bisnis yang di ungkapkan oleh Krismiaji (2010). Pengendalian internal (PI) adalah semua rencana organisasional, metode pengukuran yang dipilih oleh suatu perusahaan guna mengamankan harta kekayaannya, mengecek keakuratan dan keandalan data akuntansi perusahaan tersebut, meningkatkan efisiensi operasional, dan mendukung dipatuhinya kebijakan manajerial yang telah di tetapkan Diana dan Lilis (2011). Komponen pengendalian internal yaitu aktivitas 
pengendalian, lingkungan penegendalian, penilaian risiko, komunikasi dan informasi, pengawasan di ungkapkan oleh Mardi (2011). Hasil penelitian Jermias (2016) menjelaskan bahwa untuk menciptakan pengendalian internal tidak terlepas dari sistem akuntansi yang diterapkan oleh perusahaan.

Unsur pengendalian dalam sistem pengupahan adalah fungsi pembuatan daftar upah harus terpisah dengan fungsi pembayaran upah dan fungsi pencatatan waktu hadir harus terpisah dari fungsi operasi yang dikemukakan oleh Mulyadi (2016). Jadi, setiap fungsi harus memegang satu pekerjaan sesuai bagiannya tidak boleh ada perangkapan tugas dikarenakan dapat terjadinya penyelewengan pada proses pembayaran upah maupun proses yang lainnya. Maka dalam perusahaan harus mempunyai suatu sistem pengendalian internal dikatakan memadai jika dengan diterapkannya sistem tersebut semua tujuan perusahaan dapat tercapai. Tujuan tersebut adalah pengamanan atau menjaga aktiva yang dimiliki, memeriksa ketelitian dan kebenaran data akuntansi, menjamin adanya efisiensi dalam operasional serta menjaga agar tidak terjadi penyimpangan dari kebijakan yang telah ditetapkan, dengan demikian dapat dilihat bahwa sistem pengendalian intern mempunyai peranan yang penting sekali bagi perusahaan diungkapkan oleh Hidayat, Rahayu, dan Husaini (2013). Apalagi masalah gaji dan upah yang dianggap sensitif karena bersangkutan dengan kesejahteraan karyawan (Langi, Saerang dan Gerungai, 2019).

Perbedaan penelitian ini dengan penelitian sebelumnya tentang pengupahan produksi dimana pengupahan produksi di PT. TM ini menggunakan sistem borongan, pada umumnya beberapa perusahaan memiliki pekerja yang banyak untuk sistem borongan ini, tetapi dalam perusahaan ini proses produksi hanya melibatkan sedikit pekerja. Walaupun pekerja kasarnya hanya sedikit, pengendalian internal dalam perusahaan tersebut sangat dibutuhkan karena jika ada salah satu pekerjanya melakukan penyelewengan maka akan dapat diketahui secara cepat dan dapat langsung ditindak lanjuti oleh atasannya. Berdasarkan masalah penelitian diatas, peneliti ingin mengetahui sistem informasi akuntansi yang ada di PT. TM dalam upaya efektivitas pengendalian internal.

\section{KAJIAN LITERATUR}

Tugas utama sistem informasi dalam proses bisnis yaitu memastikan arsip file terkait sesuai dengan aktivitas operasional perusahaan, sumber daya manusia, dan pihak eksternal yang mempunyai kepentingan terhadap laporan yang dihasilkan; file yang telah dirubah menjadi informasi akan dipergunakan untuk manajemen dalam proses pengambilan kesimpulan; dan terdapat alat atau instrumen pengendalian internal guna melindungi aset perusahaan (Mardi, 2011).

Pengendalian internal merupakan seluruh konsep organisasional, tata cara pengukuran yang nantinya dipilih untuk perusahaan guna mengamankan harta kekayaanya, memeriksa keakuratan dan keandalan sebuah data akuntansi perusahaan, menumbuhkan efisiensi operasional, serta mendukung kebijakan manajerial yang sudah ditetapkan harus dipatuhi (Diana dan Lilis, 2011). Komponen pengendalian internal ada 5, yaitu (1) lingkungan pengendalian yang terdiri dari komitmen atas integritas dan nilai etika, filosofi dan gaya beroperasi, struktur organisasi, komite pengauditan dan komisaris, metode manajemen, pengaruh eksternal; (2) aktivitas pengendalian yang terdiri dari kewenangan penanganan, spesialisasi tanggung jawab, format dan penggunaan dokumen, pengamanan harta kekayaan perusahaan melalui pemantauan penuh, pemeriksaan yang independen; (3) penaksiran resiko untuk mengidentifikasi, menganalisis, dan mengatur risiko yang relevan dengan pelaporan keuangan, dampak dari perencanaan strategi dan operasional serta keuangan dan informasi akan menimbulkan risiko bisnis dan beberapa kebijakan bisa berakibat lebih besar; (4) kualitas informasi dan komunikasi agar keputusan dapat diambil lebih cepat dan akurat; (5) Pengawasan yang dilakukan dengan cara supervisi yang efektif dengan penugasan karyawan yang kompeten, penerapan akuntansi pertanggungjawaban, adanya audit internal (Mardi, 2011).

Siagian (2014) menjelaskan bahwa sistem imbalan baik itu gaji maupun upah bisa dikatakan efektif jika didasarkan pada empat prinsip yang meliputi kewajaran, keadilan, kemampuan, dan keselarasan. Qudus, Saifi dan Endang (2015) menyatakan bahwa upah dapat dibayarkan berlandaskan jam kerja, hari kerja, dan jumlah satuan produk yang sudah didapatkan karyawan pelaksana dan sesuai dengan perjanjian perusahaan dan berdasarkan perundang-undangan. Tarif upah bisa berubah-ubah tergantung ketetapan perusahaan terkait pembayaran upah misalnya berdasarkan jumlah produksi.

Menurut Wiratna (2015) pengawasian yang telah dilakukan oleh perusahaan sedemikian rupa 
ada kemungkinan gagal dilakukan, penyebab gagalnya itu antara lain adanya persekongkolan antar karyawan untuk melakukan kecurangan; kurang ditegakkannya sebuah pengawasan; tidak ada sanksi jelas bagi para pelanggar; ada kejahatan komputer, yaitu perusahaan yang sudah menggunakan komputerisasi dalam semua pencatatannya dapat dibacak oleh para hacker, yaitu orang yang dapat merubah data sehingga tidak sesuai dengan aslinya.Sistem akuntansi penggajian diperlukan untuk pengambilan keputusan oleh pimpinan perusahaan karena unsur gaji dan upah merupakan unsur yang besar dalam keuangan lembaga yang membutuhkan ketelitian dalam perhitungan, pencatatan, dan penggolongan (Agrianto, Kertahadi, dan Dwiatmanto, 2014).

Seorang manajer dapat dikatakan berhasil mengelola usahanya apabila dalam pengelolaannya secara efektif dengan dukungan sumber daya yang memadai. Sistem pengendalian internal merupakan suatu sistem yang dirancang oleh perusahaan guna melindungi semua aset perusahaan sehingga dalam melakukan kegiatan operasi perusahaan lebih efisien. Pengendalian internal dapat dikatakan mampu meningkatkan efisiensi perusahaan apabila telah memenuhi komponen pengendalian internal diantaranya lingkungan pengendalian, aktivitas pengendalian, penaksiran risiko, informasi dan komunikasi, dan pengawasan.

\section{METODE PENELITIAN}

Penelitian ini menggunakan pendekatan kualitatif deskriptif, objek penelitian ini pada PT. TM yang dilakukan pada bulan Mei-Juni 2019. Sumber data yang digunakan dalam penelitian ini yaitu sumber data primer yang diperoleh dari hasil wawancara dengan empat informan yaitu kepala PT. TM yang mempunyai peran penting dalam PT. TM tersebut, bendahara finansial yang membayar upah produksi terhadap pekerja, bendahara materiil yang mengawasi proses pada saat proses produksi, staf operasional yang berperan untuk mengawasi pada saat dilapangan peneliti memilih keempat informan tersebut karena keempat informan tersebut memiliki peran penting dalam sistem informasi akuntansi pengupahan produksi yang ada di PT. TM tersebut dan data sekunder diperoleh melalui dokumen dan arsip resmi perusahaan seperti profil PT. TM, dan struktur organisasi. Teknik pengumpulan data pada penelitian ini berupa observasi dimana peneliti mengobservasi pengawasan kepala PT. TM terhadap karyawan dan pekerja kasar, serta pengawasan bendahara materiil kepada pekerja kasar, dokumentasi. Untuk teknik keabsahan data adalah uji kredibilitas menggunakan teknik triangulasi sumber ini pencocokan hasil wawancara informan pertama dengan hasil wawancara informan ke dua, ketiga, dan keempat dari pencocokan hasil wawancara dari keempat informan tersebut maka dapat disimpulkan apakah sistem informasi akuntansi pengupahan produksi dalam pengendalian internal yang ada di PT. TM tersebut apakah sudah berjalan dengan baik atau belum, dan triangulasi teknik ini pencocokan dari hasil wawancara, dokumentasi, dan observasi yang dilakukan oleh peneliti, uji dependability, dan uji konfirmability.

\section{HASIL DAN PEMBAHASAN}

Proses pengupahan produksi pada PT. TM menggunakan sistem borongan dimana dalam sistem tersebut pekerja hanya menerima upah pada saat produksi. Akuntansi pada pembayaran upah pekerja kasar sistem informasi akuntansinya menggunakan sistem manual dan komputerisasi pada sistem manual pembayaran upah proses pencatatannya melalui bendahara materiil kemudian catatan dari bendahara materiil itu diberikan ke bendahara finansial untuk merekap pembayaran upah pekerja kasar dan untuk pembuatan laporan keuangan.

Indikator pengendalian internal pada PT. TM dapat diuraikan sebagai berikut:

\section{a. Lingkungan Pengendalian}

Lingkungan pengendalian ini adalah sarana dan prasarana yang terdapat pada perusahaan dalam menjalankan sistem pengendalian yang efektif. Hasil penelitian ini bahwa lingkungan pengendalian yang ada di PT. TM menggunakan sistem Enterprice Resource Planning (ERP) karena didalam sistem tersebut kepala UPB bisa mengawasi kinerja karyawannya. Selain dalam sistem Enterprice Resource Planning (ERP) tersebut kepala PT. TM bisa melihat semua laporan keuangan yang dibuat oleh bendahara finansiil. Hal ini didukung oleh pernyataan dengan kepala PT. TM:

"Pendayagunaan sarana dan prasarana sudah tercukupi mbak, di unit ini bawahannya harus sudah mengenal sistem ERP yang diterapkan di PT.Pertani karena sangat membantu dalam kinerja."

\section{b. Aktivitas Pengendalian}

Dalam aktivitas pengendalian ini bisa dikatakan mencapai tujuan pengendalian apabila suatu 
perusahaan memiliki aturan atau kebijakan. Di PT. TM untuk proses pencatatan pengupahan produksi ada tanda bukti kwitansi pembayaran sebagai tanda bukti pembayaran pekerja kasar dan absensi pekerja kasar, dan untuk dokumen pengupahan produksi, surat perintah produksi dalam satu hari direkap dan dijadikan acuan pembayaran upah pekerja dan dilaporkan ke bagian finansial untuk dimintakan pembayarannya. Untuk pembayaranya upahnya bagian keuangan langsung membayarkan ke mandornya kemudian mandor memberikan kepada pekerja kasar dan absensi dari mandor kemudian diberikan ke bagian keuangan, bagian keuangan mengkroscek apakah benar absensinya atau tidak. Hal ini didukung oleh pernyataan bendahara materiil dan bendahara finansiil dan Kepala PT. TM:

"Catatan pengupahannya adalah tanda bukti kwitansi pembayaran pekerja kasar, absensi pekerja kasar mbak, dokumen pengupahan produksi, surat perintah produksi dalam satu hari direkap mbak dan dijadikan acuan pembayaran upah pekerja dan dilaporkan ke bagian finansial untuk dimintakan pembayarannya."

Selain itu, pemeriksa auditnya ada 2 yaitu dari BPK dan tim independen yang ditunjuk oleh PT. TM dan dilakukan dua kali dalam setahun.

"Pemeriksa audit ada 2 mbak yaitu dari BPK dan tim independen yang ditunjuk oleh PT.Pertani dan dilakukan dua kali dalam setahun. Untuk memeriksa kinerja keuangan kepala PT. TM mempunyai buku bantu, ERP dan tanda bukti."

Untuk pengendalian saat benih masih basah kemudian dijemur atau proses pengeringan yang mengawasi saat proses pengeringan adalah bendahara materiil dan finansiil dan untuk mengukur kadar air benih tersebut yang mengukur dengan alat ukur kadar air tersebut ada bendahara materiil dan finansiil bukan pekerjanya, pekerja hanya melakukan proses pengeringan.

"Yang mengawasi saat proses tersebut ya saya mbak sebagai bendahara materiilnya dan untuk pengukuran kadar airnya juga saya yang mengukurnya bukan pekerja kasarnya."

\section{c. Penaksiran risiko}

Penaksiran resiko dirasakan belum ada kendala selama ini, karena sudah berjalan dengan sewajarnya, apa yang dikerjakan satu hari itu langsung dibayarkan. Tetapi biasanya pekerja meminta pembayaran upah dilakukan per minggu sesuai dengan borongannya dan bendahara finansial mempunyai data produksi yang dilakukan oleh pekerja tersebut dari bendahara materiil.
"Kendala proses pengupahan tidak mbak ada karena sudah berjalan dengan sewajarnya karena apa yang dikerjakan satu hari tersebut dibayarkan sesuai dengan yang dihasilkan tetapi untuk pencatatan data bendahara materiil mencatat setiap hari dan untuk proses pengupahan dibayarkan perminggu."

\section{d. Informasi dan komunikasi}

Informasi yang dihasilkan oleh sistem informasi akuntansi dapat membantu pimpinan untuk membuat keputusan bisnis yang terkait dengan operasi perusahaan. dalam PT. TM dasar acuan data proses pengupahannya adalah bendahara materiil melakukan pencatatan dan pengawasan terhadap pekerja kasar setiap hari untuk mencapai target sehingga perusahaan tidak mengalami rugi, semakin banyak proses yang bisa dihasilkan maka akan meminimalisir terjadinya kerugian perusahaan, pembayaran borongan dilakukan setiap seminggu sekali tetapi untuk pencatatan dilakukan setiap hari untuk kegiatan prosesnya misalnya dalam satu hari ada blower dan penjemuran itu dicatat berapa ronasenya nanti selama seminggu baru dibayarkan ke pekerja. Bendahara materiil melaporkan kegiatan proses produksinya selama seminggu ke bendahara finansial untuk mengetahui pekerjaan yang dilakukan terhadap pekerja kasar, pelaporan tersebut setiap hari jumat ke bendahara finansialnya dan untuk pengawasannya dilakukan setiap hari oleh bendahara materiil dan bendahara finansial. Bendahara finansial baru bisa menganalisa setelah satu minggu tersebut, apakah perusahaan mengalami kerugian atau tidak dari proses yang dihasilkan oleh pekerja. Semisal satu hari bendahara finansial belum bisa menganalisa, bendahara finansial melakukan pembayaran ke mandor setelah dibagikan ke setiap pekerja kasar.

\section{e. Pengawasan}

Pengawasan yang efektif dilakukan untuk meningkatkan kinerja dalam PT. TM ini cara pengecekan upah setiap hari dilakukan oleh bendahara materiil dalam satu hari proses apa saja yang dilakukan oleh pekerja. Bendahara materiil merinci kegiatan proses setiap harinya selama ada kegiatan produksi dan untuk data biaya diperoleh dari bendahara materiil kemudian dilaporkan ke bendahara finansial. Proses kegiatan produksi semisal ada panen padi, pekerja ikut masuk. Selama ada proses panen kegiatan untuk pekerja berjalan terus jika panen sudah berhenti pekerja diberhentikan semisal tidak diberhentikan maka perusahaan akan rugi. Selama di lapangan terkait 
pencatatan pembayaran upah pekerja ada dioperasional setelah barang masuk gudang pencatatan diserahkan oleh bendahara materiil. Bendahara materiil dan operasional setiap hari melaporkan pencatatan ke bendahara finansial, kendalanya SDM nya sedikit. Caranya pembagian tugasnya dibagi, jika pembayaran dilakukan oleh bendahara finansial semua maka tidak akan jalan semisal sekarisidenan madiun terjadi panen jadi untuk pembayarannya di bagikan ke operasional dan bendahara materiil walaupun nanti catatannya tetap dilaporkan ke bendahara finansialnya. Untuk pencatatannya itu fleksibel jadi bendahara finansial mengikut dari operasional dan bendahara materiil, untuk produksi penyalurannya tetap jalan jika ada permintaan pekerjanya tetap masuk. Untuk menganalisa permintaan 1-2 minggu nantinya packing langsung dilakukan bukan hanya satu varitas tetapi beberapa varitas untuk mengefisiensi data permintaan yang masuk, semakin cepat mendapatkan informasi permintaan maka perusahaan bisa mengatur pekerjanya. Semisalnya pekerja hanya masuk 1-2 hari tetapi menghasilkan output yang banyak maka perusahaan tidak mengalami kerugian. Jika semua wewenang pembayaran dilimpahkan ke bendahara finansial maka tidak jalan sehingga operasional dan bendahara materiil membantu bendahara finansial dalam arti membantu yang tahu dilapangan dan prosesnya apa saja yang tahu bendahara materiil dan operasionalnya setalah itu bendahara materiil dan operasional kemudian melaporkan ke bendahara finansialnya, sehingga bendahara finansial dapat mengawasi apakah data tersebut benar atau tidak dengan kata lain dikroscek antara data dari operasional dan bendahara materiil sesuai atau tidak. Untuk yang mengatur proses kegiatan produksi antara mandor dan bendahara materiil saling berkoordinasi. Jadi, pencatatanya kegiatan produksinya ada di operasional, bendahara materiil dan mandor tapi untuk pelaporan semuanya tetap diserahkan ke bendahara finansial, nanatinya bendahara finansial mengecek apakah data yang diberikan oleh bagian bendahara materiil, operasional dan mandornya sesuai dengan yang dilapangan atau tidak. Untuk selisih pencatatannya tidak ada, sebenernya staf juga mengawasi pekerja kasarnya secara tidak langsung. Upah tidak termasuk pajak karena dibawah PTKP.

Pada PT. TM tidak terdapat flowchart untuk sistem pengupahan. Jadi peneliti berusaha menggambarkan flowchart untuk sistem pengendalian internal pada sistem pengupahan yang sudah dilakukan. Flowchart tersebut dapat dilihat pada gambar 1. Peneliti juga merancang formulir yang baik untuk pencatatan di bagian pengupahan produksi, yaitu meliputi Rekap Daftar Upah (RDU) pada gambar 2, Surat Pernyataan Upah (SPU) pada gambar 3, Bukti Kas Keluar (BKK) pada gambar 4, Kartu Jam Kerja (KJK) pada gambar 5, Kartu Jam Hadir (KJH) pada gambar 6, Daftar Upah pada gambar 7 sebagai solusi untuk pengendalian pengupahan yang lebih baik di PT.TM.

Proses pengupahan pada PT. TM tidak dapat dipisahkan dengan proses produksi. Alur cerita dari proses produksi sampai dengan pengupahan dapat diutarakan sebagai berikut:

Tahapan dalam proses produksi benih adalah

1. Perencanaaan produksi, rencana produksi ini berdasarkan rencana penjualan yang memuat varietas, kelas benih, jumlah dan waktu. Perencanaan produksi ini dibuat oleh kepala UPB bersamaan dengan penyusunan RKAP, dan kemudian di otorisasi oleh kepala cabang dan kepala wilayah.

2. Penangkaran, areal penangkaran di sini dilakukan oleh kelompok tani yang terdaftar dalam penangkar UPB PT.Pertani.

3. Monitoring areal penangkaran, monitoring ini dilaksanakan oleh petugas lapangan minimal bersamaan saat mendampingi pemeriksaan lapangan oleh BPSB. Tujuan monitoring adalah untuk mengidentifikasi kondisi areal pertanaman.

4. Panen calon benih kering sawah

5. Penerimaan Calon Benih Kering Sawah (CBKS), penerimaan calon benih sawah mempunyai standar agar bisa masuk ke gudang UPB, dan pada saat pemanenan CBKS tersebut mendapat pengawasan oleh petugas lapangan (staf operasional) untuk memastikan bahwa CBKS merupakan hasl panen pada hari itu juga dan benar berasal dari areal penangkaran yang dimaksud. Pengiriman CBKS tersebut disertai dengan surat pengantar dari petugas lapangan.

6. Proses produksi, proses produksi ini dimulai dari pengeringan sampai dengan pengepakan atau pengemasan. Kegiatan proses produksi dilaksanakan oleh petugas prosesing (operator) karyawan yang di- 
tunjuk oleh kepala UPB. Tahapan proses produksi adalah

a) Pengeringan, proses ini guna mengurangi kadar air benih hingga mencapai standar yang telah ditentukan oleh PT.Pertani. Untuk proses pengeringan ini dilakukan sejumlah 15 orang tetapi jumlah tersebut belum pasti, jika dalam satu hari ada proses lainnya maksudnya ada proses blower ataupun proses pengemasan pada proses pengeringan ini jumlah orang dibagi sesuai kegiatan dalam satu hari tersebut, untuk yang membagi perorangnya adalah bendahara materiilnya dan untuk proses pengupahannya per bagian sama karena sistem borongan tersebut.

b) Pengolahan benih/Blower, dilakukan dengan memasukkan seluruh benih atau gabah yang telah memenuhi kebutuhan kadar air standar benih, pengolahan tersebut bertujuan untuk membersihkan benih dari kotoran yang tercampur. Untuk proses blower tersebut dapat dilakukan 3-4 orang dan pengawasan di lakukan oleh bendahara materiil.

c) Penyimpanan benih, dilakukan untuk memperbanyak kuantum yang akan di distribusikan ke konsumen. Untuk proses ini dilakukan sejumlah 5-6 orang dan pada saat pentimpanan benih tersebut tetap diawasi oleh bendahara materiilnya.

d) Pengambilan sampel, pengamabilan contoh benih yang akan diuji ke BPSB untuk mengetahui benih untuk dipasarkan dan diperoleh label benih yang diajukan sebelumnya. Untuk pengambilan sampel benih ini dilakukan oleh bendahara materiilnya sendiri menggunkan alat tusuk dengan mengambil 3 kali tusukan per karung dibagian atas, tengah, dan bawah karung kemudian baru ujikan ke BPSB.

e) Pengemasan, setelah dilakukan pengujian di BPSB dan layak untuk dipasarkan kemudian baru di kemas dan diberi label. Pada proses pengemasan ini dilakukan oleh pekerja kasar sekitar 4-5 orang dan diawasi oleh bendahara materiil dan mandornya.

Setiap proses produksi upah pekerja dibayarkan setiap hari jum'at dan upahnya sama setiap orang karena sistem borongan tersebut. Mekanisme pengecekan upahnya dilihat dari absensi dan proses produksi pekerja kasar, kemudian yang mencatat yaitu mandor dan bendahara materiil setelah itu catatan tersebut disetorkan ke bendahara finansial untuk melakukan pembayaran ke pekerja kasar. Untuk memperoleh data pekerja kasar sebagai acuan pembayaran upah yaitu bendahara materiil melakukan pencatatan dan pengawasan terhadap pekerja kasar setiap hari untuk mencapai target sehingga perusahaan tidak mengalami rugi. Pembayaran upah borongan tersebut dilakukan seminggu sekali setiap hari jum'at tetapi untuk pencatatan proses produksinya dilakukan setiap hari, bendahara materiil melaporkan seluruh kegiatan produksi ke bendahara finansial. Bendahara finansial melakukan pembayaran ke mandor setelah itu mandor baru memberikan ke pekerja kasar.
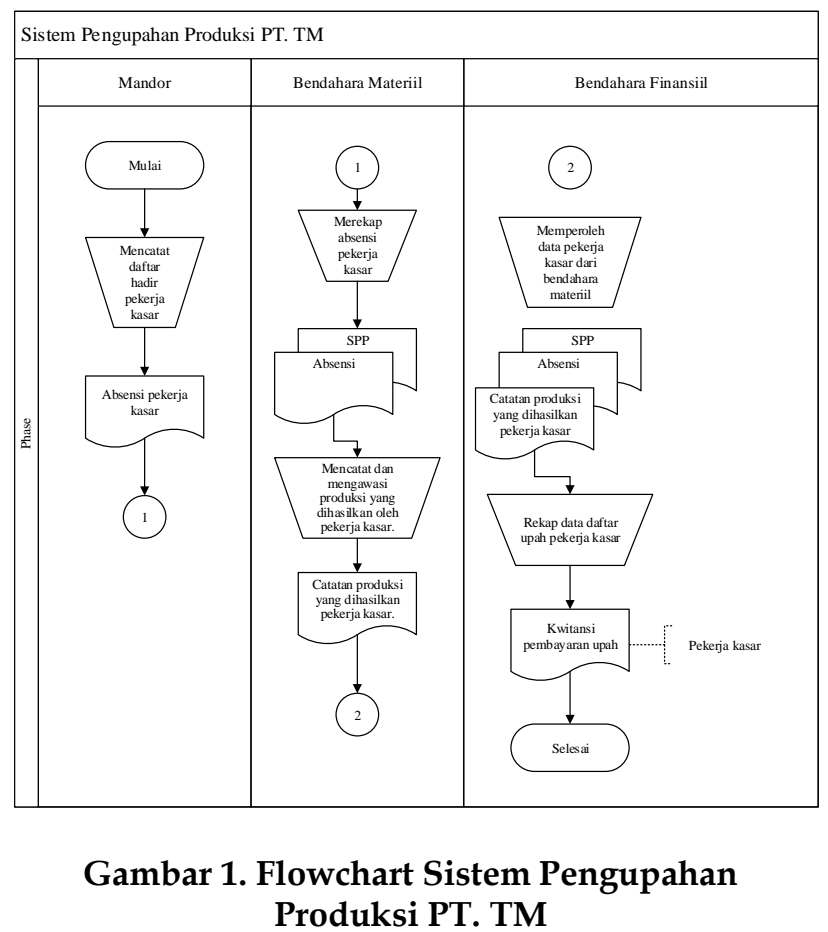

\begin{tabular}{|l|l|l|}
\hline \multicolumn{1}{|c|}{ No. } & Nama & $\begin{array}{c}\text { Upah } \\
\text { bersih }\end{array}$ \\
\hline 1. & & \\
\hline 2. & & \\
\hline 3. & & \\
\hline 4. & & \\
\hline \multicolumn{2}{|c|}{ Jumlah } & \\
\hline
\end{tabular}

Gambar 2. Rancangan Rekap Daftar Upah (RDU) 


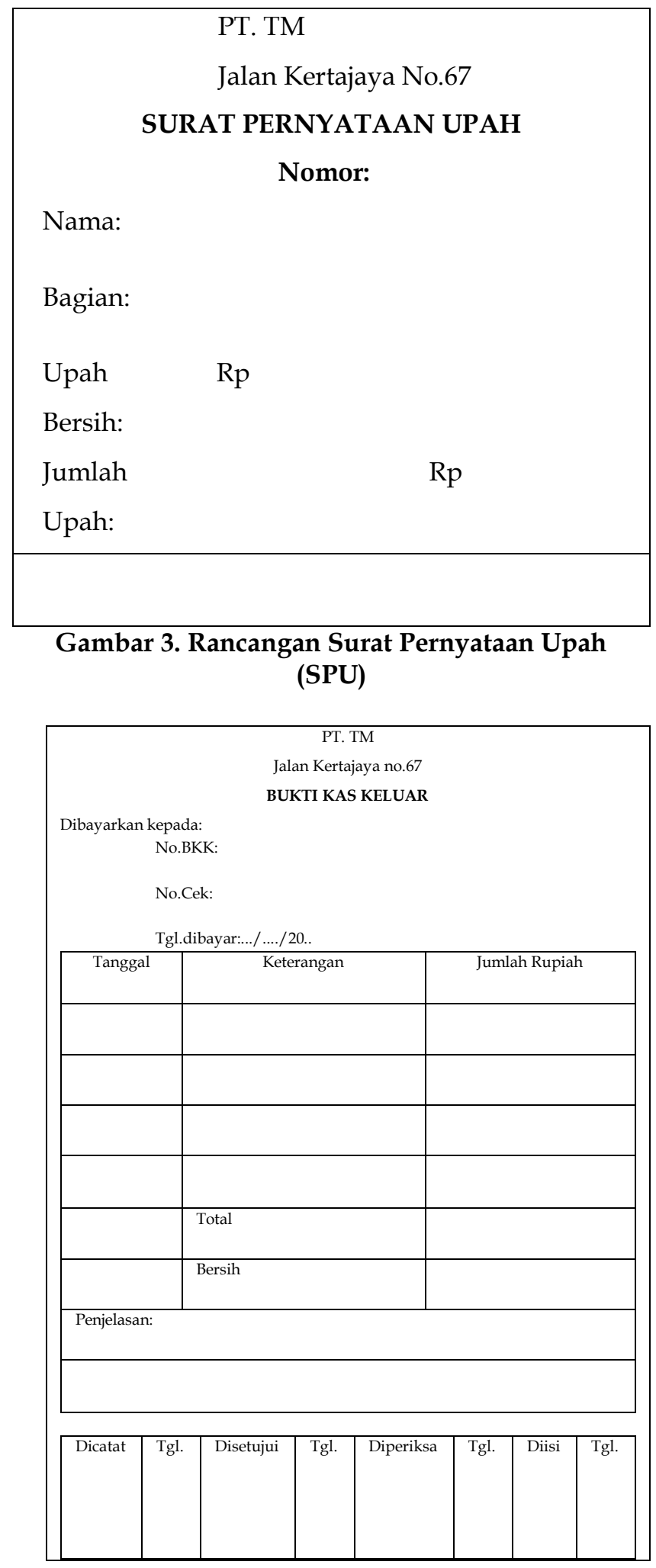

Gambar 4. Rancangan Bukti Kas Keluar

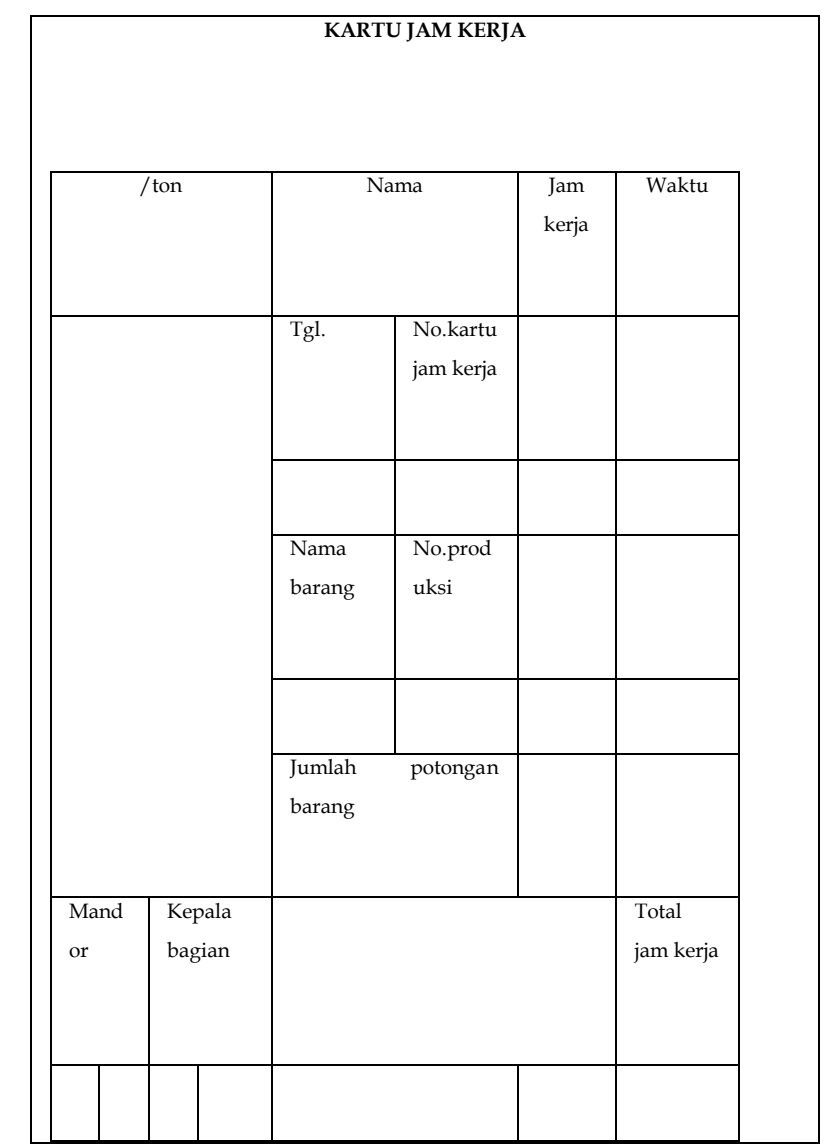

Gambar 5. Rancangan Kartu Jam Kerja (KJK)

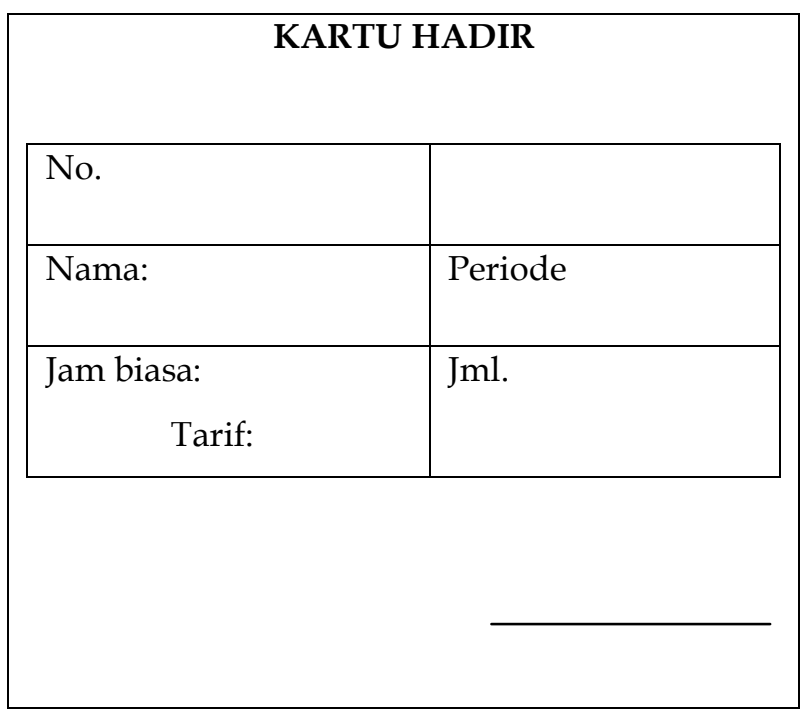

Gambar 6. Rancangan kartu jam hadir (kjh) 


\begin{tabular}{||c|c|c|c|}
\hline \multicolumn{3}{|c|}{ PT. TM } \\
\multicolumn{1}{|c|}{ DAFTAR UPAH } \\
\hline & & $\begin{array}{l}\text { Upah } \\
\text { kerja }\end{array}$ & $\begin{array}{c}\text { Total } \\
\text { upah }\end{array}$ \\
\hline & & & \\
\hline & & & \\
\hline & & & \\
\hline Total upah seluruh pekerja kasar & \\
\hline
\end{tabular}

\section{Gambar 7. Rancangan Daftar Upah}

Berdasarkan analisis data, PT. TM sudah menjalankan unsur pengendalian internal terkait dengan sistem informasi pengupahan produksi.Peneliti menarik kesimpulan mengenai sistem yang diterapkan di PT. TM kurang efektif dikarenakan masih terdapat kelemahan dengan adanya perangkapan tugas pada bagian bendahara finasiil bagian merangkap tugas dengan bagian akuntansi.Bagian akuntansi mempunyai tugas untuk mencatat, menghitung, mengalisis dan melaporkan keuangan perusahaan sesuai dengan data yang tersedia, sedangkan pada bagian finansial atau keuangan mempunyai fungsi untuk mengelola keuangan perusahaan sesuai dengan jumlah yang tertera pada perusahaan.dan pada bendahara materiil merangkap tugas menjadi bagian kepegawaian. Perangkapkan tugas tersebut jika tidak segera di selesaikan maka akan mengakibatkan kecurangan. Hasil penelitian Qudus, Saifi, dan Endang (2015) menyatakan jika pemisahan tugas atau perangkapan tugas harus dipisahkan. Pemisahan fungsi bertujuan untuk mengurangi tanggung jawab yang dibebankan pada keuangan sehingga proses penggajian serta pengupahan berjalan tepat waktu. Hasil penelitian Dewi, Atmadja, dan Darmawan (2014) juga menyatakan jika sistem akuntansi penggajian dan pengupahan digabungkan, karena perbedaan ukuran perusahaan. Selain itu, penelitian yang dilakukan oleh (Saraswati, Rahayu, dan Husaini, 2014) menyatakan jika terdapat perangkapan fungsi pada bagian Administrasi Human Resource Development (HRD) mengenai pembuatan Bukti Kas Keluar dan pencatatan ke dalam Jurnal yang seharusnya dil- akukan oleh bagian Accounting. Namun, penelitian Damayanti, Dwitatmanto, dan Azizah (2015) menjelaskan jika terdapat pemisahan fungsi payroll dengan fungsi akuntansi, fungsi pencatat waktu EDP (Electric Data Processing) dengan fungsi operasi serta adanya surprised audit secara berkala yang menunjukkan bahwa penerapan sistem penggajian dan pengupahan yang dilakukan sudah cukup efektif untuk mendukung pengendalian intern. Hasil penelitian serupa terdapat pada riset (Bachtiar, 2012) menjelaskan jika dapat terjadinya kecurangan yang disengaja dalam melakukan pengabsenan karyawan yang telat oleh karyawan lain. Hasil penelitian Danke (2012) menjelaskan bahwa masih ada pengerjaan tugas dan tanggung jawab yang tidak sesuai dengan yang telah ditugaskan pada masing-masing bagian. Namun, penelitian Agrianto, Kertahadi, dan Dwiatmanto, (2014) menjelaskan bahwa adanyapemisahan fungsi antara pembuat daftar gaji dan fungsi pembayaran gaji. Hasil penelitian Saraswati, Darminto, dan Endang (2014) menjelaskan jika bagian akuntansi masih bertanggungjawab dalam pembayaran gaji dan upah karyawan serta masih bertanggungjawab melakukan pengawasan terhadap pengisian daftar hadir karyawan dan membuat rekap daftar hadir karyawan, jumlah kehadiran karyawan masih belum dilibatkan atau tidak mempengaruhi jumlah gaji yang akan dibayarkan kepada karyawan. Hasil penelitian ini serupa dengan Retnaningtyas, Dzulkirom, dan Saifi (2015) mengatakan bahwa pada fungsi yang terkait belum menjalankan tugasnya dengan baik terlihat dari fungsi pencatatan waktu hadir kurang melakukan pengawasi proses check clock yang dilakukan oleh karyawan produksi. Namun, hasil penelitian Widyasari, Yaningwati, dan Husaini (2015) mengatakan jika sudah melakukan praktek yang sehat sehingga mendukung unsur pengendalian intern, terbukti bahwa pada formulir bukti kas keluar telah tercantum nomor urut tercetak yang ditampilkan, slip gaji diserahkkan ke bagian payroll dan karyawan.

\section{SIMPULAN}

Berdasarkan hasil analisis data dan pembahasan yang disampaikan maka sistem informasi akuntansi pengupahan produksi sesuai dengan prosedur pengupahan yang ada di PT. TM tetapi sistem pengendalian internal atas sistem informasi akuntansi pengupahan produksi belum diterapkan secara efektif karena masih memiliki beberapa kelemahan seperti masih ditemukan adanya perangkapan tugas yang dilakukan oleh 
beberapa bagian. Selain itu pemantauan kinerja karyawan dan pekerja kasar masih perlu ditingkatkan dengan memperhatikan unsur-unsur yang ada dalam pengendalian internal. Dalam melakukan penelitian peneliti mengalami keterbatasan waktu karena pada saat proses pengupahan pekerja kasar dilakukan setiap hari Jum'at. Selain itu, jika pekerja kasar tidak melakukan produksi maka peneliti tidak bisa melakukan observasi secara mendetail. Diharapkan untuk peneliti selanjutnya lebih mempertimbangkan waktu lebih efisien sehingga dapat mengobservasi sistem informasi akuntansi dan pengendaliannya secara lebih mendetail. Sehingga kepala PT. TM perlu melakukan pemisahan tugas dan wewenang yang jelas sehingga perangkapan tugas dapat diminimalkan serta bisa meningkatkan pengendalian internal perusahaan. Hal ini bertujuan untuk menghindari adanya kecurangan yang nantinya bisa merugikan perusahaan dan diperlukannya pengawasan saat pemberian upah terhadap pekerja kasar karena dalam pengupahan pekerja kasar yang menerima kwitansi diwakilkan hanya satu orang. Flowchart dalam perusahaan ini belum ada, jika sudah ada flowchart memudahkan saat melakukan pengendalian internal dan seharusnya masingmasing pegawai mempunyai bagian-bagian sendiri, tidak diperbolehkan merangkap tugas.

\section{REFERENCES}

Agrianto, R. S., Kertahadi, dan Dwiatmanto. (2014). Analisis Sistem Akuntansi Penggajian dan Pengupahan dalam Upaya Meningkatkan Efektivitas Pengendalian Internal Perusahaan (Studi Kasus pada PT. Duta Paper Prigen Pasuruan). Jurnal Administrasi Bisnis, 7(1), 1-8.

Bachtiar, E. (2012). Perancangan Sistem Informasi Akuntansi dengan Menggunakan Database Karyawan untuk Meningkatkan Keakuratan dalam Melakukan Perhitungan Penggajian pada PT. DIS. Jurnal Ilmiah Mahasiswa Akuntansi, 1(1), 86-89.

Damayanti, N., Dwitatmanto, dan Azizah, D. F. (2015). Evaluasi Efektivitas Pengendalian Intern atas Sistem Penggajian dan Pengupahan (Studi Kasus pada PT. Karyamitra Budisentosa Pandaan-Pasuruan). Jurnal Administrasi Bisnis, 3(1), 1-7.

Danke, Y. (2012). Analisis Perancangan Sistem Informasi Akuntansi pada Siklus Penggajian dalam Rangka Efektivitas Pengendalian Internal (Studi Kasus pada Perusahaan Plastik
Injection). Berkala Ilmiah Mahasiswa Akuntansi, 1(1), 20-26.

Dewi, K. A., Atmadja, A. T., dan Darmawan, N. A. S. (2014). Analisis Sistem Pengendalian Intern terhadap Sistem Akuntansi Penggajian dan Pengupahan pada Hotel "The Damai." EJournal S1 Ak Universitas Pendidikan Ganesha, 2(1).

Diana, A. dan Lilis, S. (2011). Sistem Informasi Akuntansi. Yogyakarta: CV. Andi.

Hidayat, M. T., Rahayu, S. M., dan Husaini, A. (2013). Analisis Penerapan Sistem Akuntansi Penggajian dan Pengupahan dalam Pengendalian Intern (Studi Kasus pada PT. Cahaya Marta Perkasa, Pamekasan). Jurnal Administrasi Bisnis, 6(2), 1-8.

Jermias, R. R. W. (2016). Analisa Sistem Informasi Akuntansi Mendukung Gaji dan Upah PT.Bank Sinarmas tbk. Manado. Jurnal EMBA, 4(2), 814-828.

Krismiaji. (2010). Sistem Informasi Akuntansi. Yogyakarta: UPP STIM YKPN.

Langi, B., Saerang, D. P. E., dan Gerungai, N. Y. T. (2019). Analisis Sistem Informasi Akuntansi Penggajian dan Pengupahan dalam Upaya Pengendalian Internal pada PT. Gemilang Emas Indonesia.Jurnal Riset Akuntansi Going Concern, 14(1), 148-153.

Mardi. (2011). Sistem Informasi Akuntansi. Bogor: Ghalia Indonesia.

Mulyadi. (2016). Sistem Akuntansi. Jakarta: Salemba Empat.

Qudus, I., Saifi, M., dan Endang, M. G. W. (2015). Analisis Sistem Akuntansi Penggajian dan Pengupahan dalam Upaya Mendukung Pengendalian Intern (Studi pada PT. Sun Star Motor Malang). Jurnal Administrasi Bisnis, 25(2), 1-7.

Retnaningtyas, D. T. R., Dzulkirom, M., dan Saifi, M. (2015). Analisis Sistem dan Prosedur Penggajian dan Pengupahan dalam Upaya Mendukung Pengendalian Intern Perusahaan (Studi Kasus pada Perusahaan Kacang Shanghai "Gangsar" Ngunut Tulungagung). Jurnal Administrasi Bisnis, 1(1), 1-10.

Saraswati, K. M., Rahayu, S. M., dan Husaini, A. (2014). Analisis Sistem Akuntansi Penggajian dan Pengupahan Karyawan dalam Usaha Meningkatkan Pengendalian Intern Perusahaan (Studi pada PT. Japfa Comfeed Indonesia, tbk Kantor Cabang Sidoarjo). Jurnal Administrasi Bisnis, 8(1), 1-10.

Saraswati, V., Darminto, dan Endang, M. G. W. 
(2014). Analisis Sistem Akuntansi Penggajian dan Pengupahan sebagai Upaya Mendukung Tujuan Pengendalian Intern Perusahaan (Studi pada Hotel Batu Permai Kota Batu). Jurnal Administrasi Bisnis, 15(2), 1-10.

Siagian, S. P. (2014). Manajemen Sumber Daya Manusia. Jakarta: Bumi Aksara.

Widyasari, F. D., Yaningwati, F., dan Husaini, A. (2015). Analisis Sistem Akuntansi Penggajian dan Pengupahan Karyawan Bagian Produksi sebagai Upaya Mendukung Pengendalian Intern Perusahaan (Studi Kasus pada CV Sejahtera, Pakisaji - Malang ). Jurnal Administrasi Bisnis, 27(2), 1-7.

Wiratna, V. S. (2015). Sistem Akuntansi. Yogyakarta: Pustaka Baru Press. 